IJ§ER

ISSN: 2149-5939
International Journal of Social Sciences and Education Research

Online, http://dergipark.gov.tr/ijsser

Volume: 1(2), 2015

\title{
Whistleblowing behavior in organizations and work morality interaction
}

Esra Kızıloğlu1 ${ }^{1}$

Received Date: $01 / 02$ / 2015
Adnan Çelik ${ }^{2}$

Accepted Date: $01 / 04$ / 2015

\begin{abstract}
Whistleblowing behavior has become an important subject in internal and external stakeholders of an enterprise today, when morality values become conscientious responsibility. News about the enterprises in which malpractice, bribery and inappropriate behaviors to work morality in recent years, has increased the importance of this concept. This study aimed to theoretically explain the interaction between whistleblowing behaviors and work morality in the organizations. For this purpose, first of all, work morality and whistleblowing topics have been explained and secondly, the interaction between whistleblowing behavior and work morality ics has been analyzed in a theoretic ground with being managed suitable for work morality and the role of work morality in creating whistleblowing behavior subtopics.

Keywords: Morality, work morality, business ethics, whistleblowing, news spreading
\end{abstract}

\section{Introduction}

The fast changes which we experience in ever field with globalization forced us to become an information society. Constantly changing competition rules and cultural, social and economic transformation in the world make it difficult to sustain their existence for the enterprises. In such an environment, both and enterprises and individuals have degenerated by leaving moral values which are our core values. Economic problems, especially, changed our values and exterminate the mutual trust between people. This caused problems like bribery, malpractice, favoritism, discrimination, sexual harassment. Naturally, it would be a mistake to accept that enterprises are innocent in such a situation.

Although work morality may seem like a new concept, it is a practice area of the concept called moral which has sustained its existence in work morality since the beginning of humankind. Work morality, in short, is the adoption and the practice of ethics. It is based on integrity and honesty. Enterprises face many problems when they act in accordance to work morality. Whistleblowing concept has been uncovered when these problems were noticed by the employees who are the primary customers of the enterprises.

It is whistleblowing to inform the internal and external authorities about the insidious and illegal practices in the enterprise. This phenomenon is seen in the enterprises in which there is no work morality. In the enterprises in which moral values are cared, there can be no chance of whistleblowing. Low moral standards can been seen as a reason of whistleblowing.

This study is to theoretically explain the interaction between whistleblowing behaviors and work morality. For this, first of all, moral concept and moral-ethic difference, work morality and

\footnotetext{
${ }^{1}$ Research Asst., Selçuk University, Faculty of Economic and Administrative Sciences, esraciftci@s,selcuk.edu.tr

${ }^{2}$ Prof. Dr., Selçuk University, Faculty of Economic and Administrative Sciences, adnancelik@selcuk.edu.tr 
Kızıloğlu, E., Çelik, A. (2015). Whistleblowing behavior in organizations and work morality interaction. International Journal of Social Sciences and Education Research, 1 (2), 329-341.

whistleblowing concept will be mentioned and later, the interactions between these concepts will be discussed.

\section{What is moral and ethics?}

Moral and ethical concepts are closely intertwined nowadays and generally accepted full and a clear definition cannot be made. According to the definition which was made by Turkish Language Society, moral is "Behaviors and rules which individuals are obliged to obey in a society". Ethics is defined as "Overall behaviors that parties should obey or avoid among the various professions" (TDK, 2015; www.tdk.gov.tr).

Moral is the sum of ethical behaviors, codes, principles which are accepted by certain human communities in a certain period and regulate the relations between people (Akarsu, 1998: 18). It is the sum of rules, principles, standards and values which search the accuracy and inaccuracy of certain actions of individuals and groups, good and bad sides of the people in action and in connection with the goals which those actions target, the elements which create the welfare of mankind and explain the behaviors and decisions which encourage them (Bedük, 2013: 2).

Ethics, which was originated from Greek word ethos-ethikos, consists of evaluation of all behaviors and acts of an individual from past to today whether they are right or wrong, valuable or valueless (Bedük, 2013: 2). According to Şimşek (1999), ethics is to talk about moral, in other words, to do the philosophy of moral. Ethics, which shows how individuals should behave, indicates a code of conduct or system which is based on duty and responsibilities (Bayrak, 2011: 9).

\section{The Relation between moral/ work morality and ethics/business ethics}

Moral and ethics are two of the most discussed topics in literature today. Although they are used instead of each other, there are some differences between them. For this reason, work morality and business ethics are nested concepts just like moral and ethics.

According to Maclntre (1991), moral concept is expressed with "ethics" and "moralty" concepts which are often confused. While some of the moral philosophers use these two concepts with the same meaning, most of them try to indicate the difference and relation between them when they start to analyze moral first. When we look into the moral philosophy literature, it is seen that there is a nuance and an important difference between these concepts but it is difficult to identify this difference properly (Kapu, 2009: 54).

Gök (2008) states that business ethics and work morality have differences in term of meaning, content, quality and context which they have (Gök, 2008: 3). These differences are summarized on the following table.

Table 1 . The relation between work ethics and work morality

\begin{tabular}{|l|l|l|}
\hline Dimensions & \multicolumn{1}{|c|}{ Business Ethics } & \multicolumn{1}{c|}{ Work morality } \\
\hline Origin & Thinking and philosophy & Religion and religious beliefs \\
\hline Content & Universal norms & Customs and traditions \\
\hline Reference & Philosophy of law & Moral philosophy \\
\hline Quality & General, applies to everyona & Changes from community to community \\
\hline Context & Covers the whole rules & Covers the code of conduct \\
\hline
\end{tabular}

Source: (Gök, 2008: 3) 
Kızıloğlu, E., Çelik, A. (2015). Whistleblowing behavior in organizations and work morality interaction. International Journal of Social Sciences and Education Research, 1 (2), 329-341.

When we look into the table, we can say that business ethics concept is originated from principles based on thinking and philosophy and work morality concept is originated from religion and religious beliefs. When business ethics consists of universal norms, work morality based on customs and traditions. Business ethics concepts which is based on philosophy of law is general and applies to everyone. However, work morality changes from community to community. In terms of context, business ethics covers the whole rules and work morality covers codes of conducts. The reason for ethics and morality are the same concepts is ethics in and morality philosophy and morality is a research subject of ethics. When ethics is the theory of right or wrong behaviors, morality is its practice (Bedük, 2013: 2).

If we take look at our country, it seen that both "morality" and "work morality" and "ethics" and business ethics" concepts are used frequently. However, there are controversies about in translating the concept stated as "business ethics" in foreign literature, as "work morality" or "business ethics". Although it is seen that it is sometimes translated as "business ethics", when Turkish literature is searched, it is observed that this term is translated as "work morality" and "work morality" concept is mostly used in the sources written in original language. However, in recent years, it has been seen that ethics concept is mostly started to be used as rules and principles which should be obeyed in both business and professional life and economics and management. Therefore, there is no important inconvenience in using both concepts simultaneously (Özdemir, 2009: 3). From now on, in this study, morality concept will be used as an equivalent to ethics.

\section{What is work morality?}

The evolution of the work morality concept has been not only parallel to changes and improvements in the social, political, economic and management area but also affected by these changes and improvements in these areas (Gök, 2008: 3). "Ethics in the Workplace" or "Business Ethics" came into question previously especially in USA in 1960s and 1970s, and these terms were started to be used in both our country and many other countries as "work morality - business ethics" in 1980s (Y1lmazer, 2005: 313).

Work morality has appeared by the usage of philosophy of morality in business life. When morality is to search what is right and good for people, work morality tries to understand the enterprises, their implementations and actions based on some life values (Kapu, 2009: 54). "Work morality means the morality of employer and employee. Namely, it points out the morality both employees and employers should obey" (Tabakoğlu, 2009: 219). Work morality is the analysis of principles and values which lead the way in making prudent choices in parallel to the benefits which are provided by business and economic life (Mchugh, 1992: 15).

Work morality answers the questions what are the right-wrong, good-bad, harmful-useful decisions and actions in the enterprises. It is the discipline and art of implementing the ethical principles in order to analyze and solve the subjects related to morality in the workplace (Weiss, 1998: 7). Work morality, with its basic meaning, is defined as the economic, political, social and ecologic responsibility of an institution (Diken, 1998: 476). If we are to define work morality in general and concise manner in parallel to the definitions till here;

Work morality is a discipline which is not defined in writing, guides the behaviors and principles within the enterprise, accepted by society and shows what is right and wrong in business life. 
Kızıloğlu, E., Çelik, A. (2015). Whistleblowing behavior in organizations and work morality interaction. International Journal of Social Sciences and Education Research, 1 (2), 329-341.

Work morality issues are important in the relation of enterprises with their employers, competitors, suppliers and customers. It helps managers to overcome the ethical problems by making them understand the right and wrong in their business life".

The relation between morality and enterprise comes up in the phase of indicating what individuals should target with their activities in the enterprises (what is good for people?) or which actions are right for people (Kapu, 2009: 54). According to Kapu (2009: 58), work morality should have these following processes:1- To define the differences between behavior and belief problems, 2- To decide how to define the problems,3- To decide the moral principles to obey in any case.

Work morality, is important to both employees, managers and enterprise because individuals prefer working in organizations which generally operates according to morality standards. Thanks to it, employees feel themselves better and satisfied with their work. Work morality is important to managers since it is a source which they apply to prevent their employee behaviors which are accepted as crime. Enterprises apply to work morality in order to help their employees to define the limits of the acceptable and unacceptable behaviors (Bayrak, 2011:27).

Work morality means more than behaving according to law and not violating morality rules. Enterprises are not religious, governmental, justice provider or political institutions. The most significant point which should be distinguished is to accept principles are necessities of enterprise natureas an enterprise (Novak, 1996: 50).

Baumhart lists in his work, which he conducted in 1961 in the enterprises in USA in order to research work morality, behaviors of senior managers, morality structure of industry, behaviors of other employees who are at the same level with management, lack of written morality rules in the enterprises and manager's having personal needs as factors which direct managers to unethical behaviors (Çelik, 2010:23).

\section{What is whistleblowing?}

Whistleblowing is a new concept which emerged with the scandals which took place in Enron and WordlCom in USA and Robert Maxell in Great Britain. This concept doesn't have an official and common meaning in the strict sense. This because in every country, economist and lawyers have different visions and perspectives in solving the problems (Rimoldi, 2007: 1-3).

Whistleblowing is defined as an employee's actions which he/she discloses actions, which he/she thinks illegal or unethical, to the senior managers (internal whistleblowing) or outer authorities or public (external whistleblowing) (Bouville, 2007: 1). Whistleblowing concept hasn't been inserted in strict sense in our country. If it is translated in to Turkish word for a word, it means to whistle, to blow. When we look into the academic literature, it is seen that this concept is used as whistleblowing, giving forth the unethical behaviors in the enterprises, informing, reporting unethical situations, whistling."

Whistleblowing is a point which concerns all the organizations and people because every institution faces with the risk of employing wrong (corrupted) people by being aware or unaware (Dehn, 2001: 1). According to Rotschild and Miethe (1999), is a new way of resistance for employee in controlling the endless fight between labor and management. 
Kızıloğlu, E., Çelik, A. (2015). Whistleblowing behavior in organizations and work morality interaction. International Journal of Social Sciences and Education Research, 1 (2), 329-341.

According to dictionary of Chambers, whistleblowing is to give information to competent authority about illegal and discrete acts (Dehn, 2001: 1). Whistleblowing, at the same time, can be thought as a special way of conflicts between the employees at the same level and interest groups of the enterprises. It is quite hard for individuals to identify and notice whistleblowing until the facts come up very well (Petersen and Farrel, 1986: 4-6).

Whistleblowing is still a controversial topic; some consider the ones who disclose things as traitors who violate the loyalty norms and some consider them as heroic defenders of these values which they think more important than enterprise loyalty (Rothschild and Miethe, 1999). Besides, while writers say that whistleblowing gives critical information to the enterprise about producing more reliable products, providing better work conditions and noticing tricky practices, which is positive side of whistleblowing. On the other hand, as negative side of whistleblowing, writers say that it harms the authority of the organization, organizational unity and public image (Pierson et al, 1993: 58). Whistleblowing has four important factors in context. These are (Dasgupta and Kesharwani, 2010: 57- 58):

1. Person who gives forth the not-moral (unethical) behaviors

2. Wrong behavior to be reported or complaint

3. Organization, person or groups related to the not-moral (unethical) behaviors

4. The party which the person complains who announces the unethical behavior.

The person who starts the whistleblowing process is called whistleblower (Özler et al, 2010: 172). Everyone, no matter they are inside or outside, who wants to uncover the people who abuse or act wrongly, is a whistleblower (Rimoldi, 2007: 1-3). These people believe that the task which is given to him/her or the action which he/she witnesses, may give harm to third parties or to human rights (Gökçe, 2014, 438). They uncover the examples like negligence, abuse or threats which includes misusing the existing task or insufficiency (Ray, 2006, 438). In some cases, individuals may not want to be whistleblower. If individuals notice a malpractice or important irregularities in the enterprise, the have three options (Dehn, 2001: 3): 1 . To keep quiet 2. To whistleblowe/whistle to someone from inside or person in charge 3. To whistleblowe/whistle to the authorities or media

Figure 1. Whistleblowing process

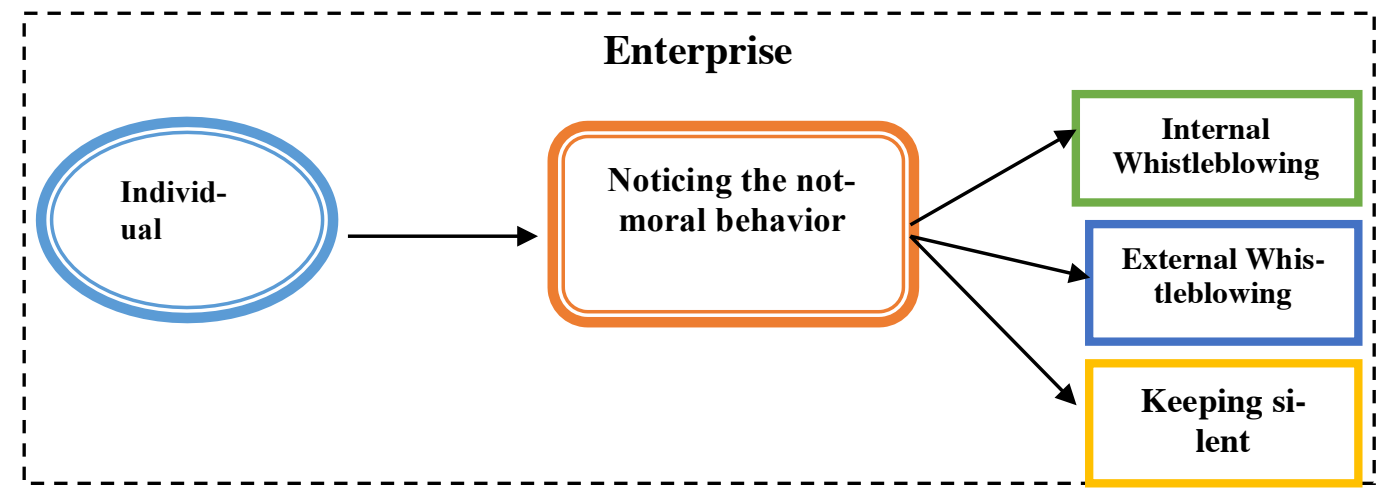

It is not easy for an employee to tell on what he/she witnesses. Decision to tell on wrong behaviors includes not only moral and psychological sides but also a big risk factor (Rimoldi, 2007: 1-3). This risk may cause employee to be fired, dismissal and even mobbing. Even though 
Kızıloğlu, E., Çelik, A. (2015). Whistleblowing behavior in organizations and work morality interaction. International Journal of Social Sciences and Education Research, 1 (2), 329-341.

the individual feels himself/herself comfortable in all conscience, he/she may choose to keep quiet because of economic, psychological, environmental and family reasons.

When the individual refuses to keep quiet, he/she has two options. He/she either informs the authorities (internal whistleblowing) or tell the media or outsider authorities (external whistleblowing). Common view is whistleblower's handling the unethical actions with the management. If the problems cannot be solved inside the institution (not being believed, covering up, people, who were reported, involving), media or outsider authorities are applied as a last resort. Consequently, in the event of facing any not-moral (unethical) behaviors in the organization, it necessary complete certain processes in order to uncover it. Here are these processes (Quoted from Özler et al, 2010: 172):

-Apply to manager in the first place

-Discuss this issue with your family

- Contact with the people in the other levels if the relevant manager is insensitive

- Contact the one who is in charge of ethics in the organization or ombudsman (bureau to investigate and report illegal and/or unethical claims in the organization)

- Consider contacting relevant people outside the organization

-Apply to any relevant person outside the organization or an institution and quit the job.

It is misunderstood in some cases to announce the not-moral (unethical) behaviors (whistleblowing) in the enterprise. In order to mention whistleblowing, first of all, actions in the enterprise shouldn't be legal, they should be illegal. For this reason, employee's voicing, who are not pleased with the organization's making change or doing a positive regulation in order to increase organizational efficiency and the performance, this illegal situation isn't whistleblowing (Near and Miceli, 1985: 3).

Whistleblowing is likened to a two-edged sword in terms of its consequences because it is seen that while some whistleblowers are awarded, some are punished. For example, David Welch was fired from Bank of Floyd since he whistled in 2002 but Cynthia Cooper, Sherron Watkins and Coleen Rowley were awarded with "Men of the Year" by Time magazine since they whistled in 2003 (Gökçe, 2014: 262).

Whistleblowing is done in two ways; official and unofficial. In official whistleblowing, informer report the error, which he/she witness institutional. While doing this, he/she reports according to the communication channels which is defined by the organization. In unofficial whistleblowing, informer tells the wrong actions to a friend or someone he/she trusts (Park et al, 2008: 292-934).

\section{Whistleblowing behavior and work morality interaction}

To understand the whistleblowing and work morality interaction, it must first be known how important to manage the enterprises according to work morality and its consequences because whistleblowing is an inevitable result in the enterprises in which work morality rules and principles are lack. 
Kızıloğlu, E., Çelik, A. (2015). Whistleblowing behavior in organizations and work morality interaction. International Journal of Social Sciences and Education Research, 1 (2), 329-341.

\section{a) To be managed according to work morality}

"A good work morality creates a good enterprise." statement is accepted by many researchers. In the researches it seen that if the enterprises act according to morality, they develop long-term (Yurdakul, 2013: 21). It is both a duty for inner and outsider parties and a necessity in terms of social development and economic growth to manage an enterprise according to work morality. It is considered first step to depend on moral rules for a good reputation and absolute success.

Work morality pay attention to the moral sides of behaviors and goals instead of private and personal morality in an enterprise. Work morality guides the social groups in evaluating their politics, principles and decisions. However, personal moralityis too important to pay attention with work morality because wrong or unethical behaviors of the managers, who make decisions, may harm the image of the enterprise. But, a manager's moral courage in a very important and critical issue may stop all unethical tendencies in an enterprise (Özgener, 2009: 48).

Morality problems to appear in an institution may harm other people. To perform activities appropriate to work morality isn't considered as senior executives' personal decision or choice, it is seen as an organizational necessity (Güney, 2006: 140). Enterprises which have moral prestige attract honest, decent and best employees. So that, they attract customers, consumers who want to do business with honest and decent people and build lasting relationships with them. Enterprises gain their prestige, which based on honesty, by making morality first priority for every employee (Beyster, 1998: 318). If we are to list the reasons why work morality is becoming more important day by day, we can say (Tutar et al, 2003: 145):

1. It is related to social responsibility which develops with public pressure to work morally.

2. To realize that good morality is identical to good work.

3. Executives' perception of discussions about morality and business life aren't threats or weakness, but a natural extension of today's industries to achieve perfection and high quality attempts.

4. Gaining importance of various interest groups to balance their benefits.

5. Spreading of the thought that relationships between both individuals and enterprises should be based on the reality that mutual trust and respect to each other's benefits.

In an organizations, if just one person behaves unethical, it may cause others to behave like this. For this reason, it is not enough to behave morality in only one area, principles and standards suitable for morality should be in effect in all other areas (Aktan, 2001: 2-3).

There are some costs that enterprises, which obey the work morality rules, have to meet. These are customer dissatisfaction, declining productivity and profit, indifference becoming the norm towards the method and processes, the formation of the atmosphere of fear and destructive competition in the work place, ensuring cooperation and solidarity becoming difficult in business environment, high stress in employees and managers, increasing of the non-respect behaviors among who share the business environment. All of them causes the enterprise to lose reputation and sales (Quoted from Şahin and Yıldırım, 2008: 61).

Work morality gives certain responsibilities to not only the firm but also to employees in the firm-employee relation since it has norms which regulate mutual relations system among all social 
Kızıloğlu, E., Çelik, A. (2015). Whistleblowing behavior in organizations and work morality interaction. International Journal of Social Sciences and Education Research, 1 (2), 329-341.

actors who interact in the socio-economic process. What comes first in the list of these responsibilities are employee's loyalty to employment contract, working disciplined and honestly, avoiding selfishness and flattery, not leaking the secrets about the firm's production, employment and marketing, avoiding disgraceful actions, obeying others rules of representing the firm and so on (Illhan, 2005: 265).

\section{b) Role of work morality in creating whistleblowing behavior}

Whistleblowing is an issue which is approached morality perspective. In literature, while explaining whistleblowing, some writers use ethics and morality synonymously and some others use morality a special type of ethics. If we think that ethics is a narrower and morality is a wider concept, we can say that business ethics used while explaining whistleblowing is actually work morality (Bouville, 2007: 2).

The interaction between whistleblowing behavior and work morality starts at the point where unethical managements and behaviors are seen in the enterprises. In most of the institutions, there are many moral conflicts and problems. In the point where employees' personal moral values and enterprise's or managers' purposes and goals collide, work morality is damaged. In such an environment, employee, who witness events which contradict his/her own morality rules, would like to exhibit whistleblowing if he/she thinks that these events are contradictory to work morality.

Whistleblowing will be seen less in the enterprises which make a point of moral management principles and of which employees adopt these principles. Besides, enterprises which are managed according to moral rules will be protected from the bad reputation which the enterprises, which are managed unethical practices, have. When it is useful only in short term for enterprise to increase its profits by fiscally exhibiting unethical behaviors, it causes the enterprise to get damaged in long term. Apart from this, it is much easier for enterprise, of which basis is solidly founded in moral sense, to answer the different demands and it becomes inevitable to gain both parties', customers and employees, respect (Güney, 2006: 44).

Figure 2. Not-Moral (Unethical) Behaviors and Whistleblowing

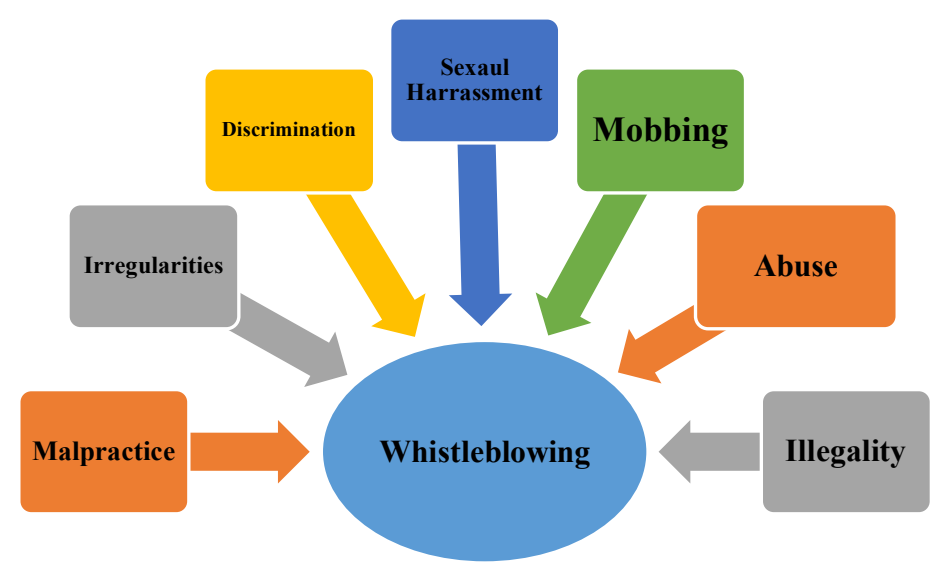

All of the enterprises, intentionally or unintentionally, behaves not suitabe to morality. In literature, these behaviors are generally listed as bribery, malpractice, sexual harrassment, conflict of interest and mobbing. These behaviors, which are not suitable to work morality, cause whistleblowing behaviors at the same time. 
Kızıloğlu, E., Çelik, A. (2015). Whistleblowing behavior in organizations and work morality interaction. International Journal of Social Sciences and Education Research, 1 (2), 329-341.

According to Ray (2006), it shows that work morality in an institution is unsuccessful, not to support the individuals who exhibit whistleblowing behaviors against the intrusion of professional standards (Ray, 2006: 438). Judd considers whistleblowing as the most ethical dilemma, which is the conflict of values. In whistleblowing, informant's moral judgment and reasoning should be right. Inner whistleblowing represents the organizations which lost its moral compass and which is substantially defective in term of ethics. Informants are among the people who are dedicated themselves to their jobs and organizations, who sympathize the system. If the enterprise do not support the employee who whistles the unethical values inside the organization, it will follow an unsuccessful way (Ray, 2006: 439-441).

In some cases, to announce the unethical and illegal situations which they encountered in the workplace caused individuals to be labeled bad. It is a conscientious and humanistic behavior of the whistleblowers to take part in mentioned cases and whistle. It will be extremely wrong behavior to label the people bad who whistles since it is just an well-intentioned behavior (Bouville, 2008: 579-584; Sayğan and Bedük, 2013: 5).

When we look into some the studies which issue work morality-whistleblowing relation in literature, we see that these results have been reached;

According to Özler and his fellows (2010), work morality ${ }^{1}$ concept, which is identified as knowing what is right or wrong and doing the right thing, expresses nearly the same statements with whistleblowing, which is defined as announcing the wrong practices or unethical actions and behaviors in an organization. It is expected from an individual, who has work ethics, to inform the authorities inside and outside the institution about wrong practices which he/she encounters. Likewise, it will be an expected behavior to report a colleague who has unethical and wrong behaviors in his/her job to related people or institutions. It will be appropriate to think that people who have business administration ethics will be volunteered and eager whistleblowers. For this reason, it can be said that whistleblowing has close relation with work ethics, professional ethics and business administration ethics, which form the three basic field of ethics.

A study which was conducted by Finn and Lampe in 1992 concluded that there is a positive relation with moral behavior and whistleblowing. Bouville (2008) emphasizes in his study what determines if whistleblowing is a moral behavior is the way which he/she follows to achieve his/her goal. It is said that employees' whistleblowing behaviors on an issue about health, security and payments are unethical. Likewise, Arnold and Ponemon (1991) concluded that low morality level of employees causes whistleblowing (Seifert, 2006: 6; Özler et al, 2010: 176-178 Bouville, 2008: 1-12).

When we evaluate whistleblowing concept by basing the general morality rules which form work morality basis, we can reach the following conclusions (Esen and Kaplan, 2013: 37);

- $\quad$ Pragmatist morality approach: In this approach, intention is not important but result is. For this reason, before making a decision, whistleblower should do a cost-benefit analysis and choose the solution that will benefit most by considering all the alternatives. Even though he/she knows that there is a risk because of announcing what he/she witnessed, he/she will think that it is a moral behavior to do whistleblowing by assuming a large mass will be affected.

\footnotetext{
${ }^{1}$ Writer has preferred using work ethics in work morality-work ethics distinction. Work ethics concept, which the writer mentioned, has the same meaning with work morality in terms of meaning and context, which is mentioned in our study.
} 
Kızıloğlu, E., Çelik, A. (2015). Whistleblowing behavior in organizations and work morality interaction. International Journal of Social Sciences and Education Research, 1 (2), 329-341.

- Kant's absolute order approach: According to this approach, while doing a behavior, result is not important but intention is. There are universal rules for human's good, equality and justice and these rules are certain. According to Kant, it is not ethical if you witness some cases like trying to show the enterprise is profitable by manipulating the numbers. In Kant's point of view, not to be unjust and behaving fair is needed and in these behaviors intentions are important.

Whistleblowing, which is an organizational loyalty example, is not as innocent point as it is considered. It is a moot point an employee's uncovering his/her colleagues or the institution which he/she works for by showing great courage instead of keeping quiet since whistleblower betrays to concept of loyalty to colleague by denouncing his/her colleague who harms the image or reputation of the institution. When it is considered that disloyalty is an unethical behavior, is it more ethic not to ignore mistakes and announce or loyalty? It is quite difficult to answer this question. For this reason, the idea to see whistleblowing as a necessity or an innocent motivation and the idea to see it as heroism contradict with each other and is considered inconsistent morally. (Bouville, 2008: 584; Aktan, 2006: 7-8; Özler et al, 2010: 183-184). According to Richard DeGeorge (2004), whistleblowing can be accepted legitimate under some circumstances. These are (Aktan, 2006: 7-8); 1. If the cost of illegal and/or unethical behavior to the society is too serious and in higher dimensions, 2 . If the people who have information, informed the senior management about their worries on this point, 3 . If the people who have information got no satisfying attention and they are desperate after they informed the senior management, 4. If the whistleblower shared his convincing evidences with an authority whom he/she thinks is rational and objective and cited the wrong behaviors toward that person and provided the evidences, 5. If the whistleblower thinks that the current wrong practice will come to an end by informing the public about the event.

Management's attitude and organizational trust are important in actualizing the whistleblowing behaviors. Although whistleblowing isn't subjected to business law at the desired level since it is a new concept, management should provide a trust environment which will make the employees feel comfortable by analyzing this concept well. For this, employees who report unethical behaviors shouldn't be judged, scolded and the issue should be taken serious. It is one another point to keep whistleblower's name secret. Consequently, for the success of the behaviors, following circumstances should be known;

- Making the work morality rules written and have work morality and values adopted

- Preferring employees who have higher moral values in recruitment

- Creating an organizational based on mutual trust and understanding

- Making a crisis plan against probable whistleblowing events

- Training the employees on who to inform whistleblowing events

- Explaining the difference between spies, gossip while denouncing whistleblowing behaviors

- Analyzing the place of whistleblowing activities in law and act

- Not underestimating whistleblowing situations under no circumstances

- Keeping whistleblowers away from pressure and threats by keeping their names secret

\section{Result}

Corruption, bribery and many benefit problems in the business life are under the work morality scope. Work morality concept, which was especially adopted by businesses and academia, has been an essential point for the enterprises to compete and survive because in today's world where 
Kızıloğlu, E., Çelik, A. (2015). Whistleblowing behavior in organizations and work morality interaction. International Journal of Social Sciences and Education Research, 1 (2), 329-341.

there are no borders, enterprises which have higher moral values can survive. However, there is a point which should be remembered; work morality shouldn't be an approach applied by the enterprises which only focus on profitability. Work morality, first of all, is an applied ethics. It is necessary for a more livable world of mankind's behaving according to ethic rules such as honesty, righteousness, trust, loyalty.

Whistleblowing which puts forward concepts like conscience, virtue and loyalty, occur as a result of employees' informing the relevant authorities about inaccuracies in the institutions they work for since they think of their enterprises' interests and public welfare. The people who announce these wrong behaviors are called informant, whistleblower in the literature. Whistleblowers in the enterprises have higher moral values. They are brave enough to inform the authorities about the unethical behavior they encounter because it may cause some results like pressure, fire, lawsuit mobbing etc. to inform these wrong behaviors.

Enterprises should be managed according to work morality so that managers avoid whistleblowing behaviors. For this reason, human resources departments have great roles. First of all, enterprises should hire the ones who have higher moral values and work morality rules should be in written. Besides, management and all the employees should avoid seeing the whistleblower as fink, traitor, backbiter or problem maker. For this, educations, seminars and conferences should be held about work morality and whistleblowing concepts to the employees.

In our world where the number of the people who behave virtuous declines, it is unfortunate that not- moral (unethical) behaviors are now accepted normal. We need to prevent these corruptions and adopt human values. It should be noted that, whether a human or an organization, no one can be successful in long-term unless they adopt moral values.

\section{References}

Akarsu, B. (1998), Felsefe Terimleri Sözlüğ̈̈, İnk1lâp Yayınları, İstanbul

Aktan, C.C. (2001). Temiz Bir Toplum Yapısı Oluşturulmasında Toplam Ahlak Yönetimi Perspektifi: Yolsuzlukla Mücadele Stratejileri. Ankara: Hak-İş Yayınları.

Aktan, C.C. (2006). Organizasyonlarda Yanlış Uygulamalara Karşı Bir Sivil Erdem, Ahlaki Tepki ve Vijdani Red Davranış1 :Whistleblowing, Mercek Dergisi:1-13.

Yılmazer, A. (2005). Belediye Yöneticilerinin İş Ahlakı ve Sosyal Sorumluluğa Yönelik Tutumlarının İncelenmesi: Adapazarı Büyükşehir ve Merkez Belediyesi"n de Bir Araştırma, Sakarya, Siyasette ve Yönetimde Etik Sempozyumu , 18-19 Kasım.

Aydın, U. (2002). İş Hukuku Açısından İşçinin Bilgi Uçurması (Whistleblowing), Anadolu Üniversitesi Sosyal Bilimler Dergisi,2 (2):79-100

Bedük, A. (2013). Karşılaştırmalı İşletme Yönetim Terimleri Sözlüğü, 3. basım Atlas Yayınevi,Konya

Beyster, J.R. (1998). Ahlakı ve Girişimciliği Pekiş̧tirmek (çev. G. Bulut), Rosen, R. H. (Ed.), İnsan yönetimi: 318-328, İstanbul: MESS Yayınları.

Bouville, M. (2007). Whistle-blowing and Morality, Journal of Business Ethics: 1-12 (doi: $10.1007 / \mathrm{s} 10551-007-9529-72)$

Çelik, S. (2010). İş Ahlakı Uygulamalarının Çalışan Memnuniyeti İle İlişsisi, İş Ahlakı Dergisi,3 (5): 2140. 
Kızıloğlu, E., Çelik, A. (2015). Whistleblowing behavior in organizations and work morality interaction. International Journal of Social Sciences and Education Research, 1 (2), 329-341.

Dasgupta, S. and Kesherwani, A. (2010). Whistleblowing: a survey of literature. The IUP Journal of Corporate Governance, 9 (4): 57-70.

Dehn, G. (2001). Whistleblowing:A New Perspective. (iacconference.org/documents/cs60a.pdf)

Diken, A. (1998). İşletmelerde İş Ahlâkı ve Sosyal Sorumluluk İlişkisi. Siyasette ve Yönetimde Etik Semроzуити, Adapazarı

Esen, E. ve Kaplan H.A. (2012). İşletmelerde Ahlaki Olmayan Davranışların Duyurulması (Whistleblowing), Dokuz Eylül Üniversitesi Sosyal Bilimler Enstitüsü Dergisi, 14 (2): 33-52.

Gök, S. (2008). İş Etiği İle İş Ahlakı Arasındaki İlişki Ve Çalışma Yaşamında İş Etiğini Etkileyen Faktörler, Uluslar Arası Insan Bilimleri Dergisi, 5 (1): 1-19

Gökçe, A.T. (2014). Okullarda Bilgi Uçurma: İş Doyumu Ve Örgütsel Bağlılık İlişkisi, Dicle Üniversitesi Ziya Gökalp Eğitim Fakültesi Dergisi, 22:261-282.

Güney, S. (2006). Ahlâki Liderliğin Kavramsallaştırılması ve Ahlâki Yönetimde Liderliğin Rolü, Celal Bayar Üniversitesi İ.I.B.F. Yönetim ve Ekonomi 13:135-148.

İlhan, S. (2005). İş Ahlâkı: Kuramsal Bir Yaklaşım Afyon Kocatepe Üniversitesi Sosyal Bilimler Dergisi, $7(2): 258-275$.

Kapu, H. (2009). Akademik Bir Disiplin Olarak İş Ahlâkı İşletmelerde İş Etiği (Editör: Sabri Orman Ve Zeki Parlak). İstanbul Ticaret Odası. Yayın No: 2009-23, İstanbul.

Mchugh, F. PJ. (1992). İş ahlakı. İstanbul: TÜSİAD Yayınları.

Near, J.P. and Miceli, M.P. (1985). Organizational Dissidence: The Case of Whistleblowing. Journal of Business Ethics, 4, 1-16.

Novak, M. (1996). “Business Ethics and the Role of the Corporation”, İçinde: Business Ethics: Case Studies and Selected Readings, Ed.Marianne M. Jennings, United States of America: South Western, 1996, ss.49-52.

Özdemir, S. (2009). Günümüz Türkiye'sinde Akademik İş Ahlâkı Çalışmalarına Genel Bakış. Işsletmelerde İş Etiği (Editör: Sabri Orman Ve Zeki Parlak). İstanbul Ticaret Odası. Yayın No: 2009-23, İstanbul.

Özgener, Ş. (2000). İş Ahlakı ve Sosyal Sorumluluk: İmalat sanayiinde bir uygulama, Doktora Tezi, Selçuk Üniversitesi sosyal bilimler enstitüsü, Konya.

Özler, D.E., Şahin, M.D., Atalay, C.A. (2010). Teorik Bir Çerçevede Whistleblowing- Etik İlişkisi, Eskişehir Osmangazi Üniversitesi Sosyal Bilimler Dergisi, 11(2):169-194.

Park, H., Blenkinsopp, J., Oktem, M. K., Omurgonulsen, U. (2008). Cultural Orientation And Attitudes Toward Different Forms of Whistleblowing: A Comparison of South Korea, Turkey, And The U.K. Journal of Business Ethics, 82, 929-939.

Petersen, J. C. And Farrell, D. (1986). Whistleblowing: Ethical and Legal Issues in Expressing Dissent. Kendall /Hunt Publishing,ABD.

Pierson, J.K., Forcht, K.A. and Bauman, B.M. (1993). Whistleblowing: an Ethical Dilemma, Australasian Journal of Information Systems, 1 (1): 58-62

Ray, S.L. (2006). Whistleblowing and Organizational Ethics, Nursing Ethics, 13 (4): 438-445.

Rimoldi, C. (2007). Whistleblowing At Work: Ethıcal And Jurıdıcal Issues, Corso di Laurea Magistrale in Giurisprudenza, Unıversità Carlo Cattaneo,Italy

Rothschild, J. and Miethe, T.D. (1999), 'Whistle-blower disclosures and management retaliation'. Work and Occupations 26, 107-128. 
Kızıloğlu, E., Çelik, A. (2015). Whistleblowing behavior in organizations and work morality interaction. International Journal of Social Sciences and Education Research, 1 (2), 329-341.

Sayğan, S. ve Bedük, A. (2013). Ahlaki Olmayan Davranışların Duyurulması (Whistleblowing) ve Etik İklimi İlişkisi Üzerine Bir Uygulama, Dokuz Eylül Üniversitesi İktisadi ve İdari Bilimler Fakültesi Dergisi, 28 (1):1-23.

Seifert, D. L. (2006). The Influence of Organizational Justice on the Perceived Likelihood of Whistle-Blowing, Washington State University College of Business, Doctor of Philosophy.

Bayrak, S. (2011). Bankacılık Sektöründe Çalı̧̧anların İş Ahlakı Yönünden Analizi: İstanbul Bölgesinde Bir Araştırma, Yüksek Lisans Tezi, Sakarya Üniversitesi Sosyal Bilimler Enstitüsü, Sakarya

Şahin, L. ve Yıldırım, K. (2008). İşletmelerde İş Ahlakı Uygulamaları İçin Genel Çerçeve, İşs Ahlakı Dergisi,1 (1), 55-66.

Tabakoğlu, A. (2009). Türklyede İş Ahlâkı Geleneği Iş̧letmelerde İs Etiği (Editör: Sabri Orman Ve Zeki Parlak). İstanbul Ticaret Odası. Yayın No: 2009-23, İstanbul

Tutar, H. ve Yılmaz, M. K. ve Erdönmez, C. (2003), İșletme Becerileri Grup Calıșması, Ankara: Nobel Basımevi.

Weiss, J.W. (1998), Business Ethics: A Stakeholder and Issues Management Approach, 2nd Edition, The Dryden Press, New York.

Yurdakul, M. (2013). IŞs Ahlakında Etik İklim: Bireysel Ve Kurumsal Özellikler Açısından Etik İklimin Bankacılık Sektöründe Araştırılması, İstanbul Üniversitesi Sosyal Bilimler Enstitüsü, İstanbul. 